\title{
In vitro establishment of pepper-rosmarin nodal segments
}

\author{
Arie F Blank ${ }^{1}$; Andréa S da Costa ${ }^{1}$; Maria de Fátima Arrigoni-Blank²; Aline B de Mendonça1 ${ }^{1}$ Ana da S \\ Ledo $^{3}$
}

${ }^{1}$ UFS-DEA, Av. Marechal Rondon s/n, B. Rosa Elze, 49100-000 São Cristóvão-SE; ${ }^{2}$ UFS-Campus Prof. Alberto Carvalho, Av. Vereador Olímpio Grande s/n, 49500-000 Itabaiana-SE; ${ }^{3}$ Embrapa Tabuleiros Costeiros, Av. Beira Mar, 3250, $49025-040$ Aracaju-SE;

afblank@ufs.br

\begin{abstract}
Pepper-rosmarin (Lippia sidoides Cham.) is a native medicinal plant from the Brazilian biome Caatinga. Its high economical importance comes from the antimicrobial properties of thymol and carvacrol, both present in the pepper-rosmarin essential oil. Nodal segments of pepper-rosmarin were established in vitro to evaluate different growth regulators. We tested four concentrations of IBA (0.0; 0.01; 0.05; and $\left.0.1 \mathrm{mg} \mathrm{L}^{-1}\right)$ combined with six concentrations of BAP $\left(0.0 ; 0.1 ; 0.5 ; 1.0 ; 2.0\right.$; and $\left.4.0 \mathrm{mg} \mathrm{L}^{-1}\right)$ in assay 1 ; five concentrations of NAA $\left(0.0 ; 0.1 ; 0.25 ; 0.5\right.$; and $\left.1.0 \mathrm{mg} \mathrm{L}^{-1}\right)$ in assay 2; two concentrations of NAA $\left(0.0\right.$ and $\left.0.01 \mathrm{mg} \mathrm{L}^{-1}\right)$ combined with five concentrations of kinetin $\left(0.0 ; 0.25 ; 0.5 ; 1.0\right.$; and $\left.2.0 \mathrm{mg} \mathrm{L}^{-1}\right)$ in assay 3 ; five concentrations of IAA $\left(0.0 ; 0.5 ; 1.0 ; 1.5\right.$; and $\left.2.0 \mathrm{mg} \mathrm{L}^{-1}\right)$ in assay 4 ; and five concentrations of $\mathrm{GA}_{3}(0.0 ; 0.1 ; 0.5 ; 1.0$; and 1.5 $\mathrm{mg} \mathrm{L}^{-1}$ ) in assay 5. The use of BAP, IBA, NAA and KIN did not influence the number of shoots. The addition of $0.1 \mathrm{mg} \mathrm{L}^{-1}$ of NAA at the culture medium resulted in larger shoot length per explant, while the concentration of $1.0 \mathrm{mg} \mathrm{L}^{-1}$ of kinetin promoted larger shoot length in general. $\mathrm{GA}_{3}$ did not affect the elongation of pepperrosmarin shoots when cultivated in vitro.
\end{abstract}

Keywords: Lippia sidoides, medicinal plant, micropropagation, growth regulator.

\section{RESUMO}

Estabelecimento de segmentos nodais de alecrim-pimenta in vitro

O alecrim-pimenta (Lippia sidoides Cham.) é uma planta medicinal nativa da Caatinga, também conhecida como alecrim-pimenta, alecrim-bravo e alecrim-do-Nordeste. Possui propriedades antimicrobianas, graças à presença de timol e carvacrol em seu óleo essencial, o que lhe confere grande importância econômica. Este trabalho teve por objetivo estabelecer segmentos nodais do alecrimpimenta in vitro testando diferentes reguladores de crescimento. No ensaio 1 foram testadas quatro concentrações de $\operatorname{AIB}(0,0 ; 0,01 ; 0,05$ e $\left.0,1 \mathrm{mg} \mathrm{L}^{-1}\right)$ combinadas com seis concentrações de BAP $(0,0 ; 0,1$; 0,$5 ; 1,0 ; 2,0$ e $\left.4,0 \mathrm{mg} \mathrm{L}^{-1}\right)$; no ensaio 2 , cinco concentrações de NAA $\left(0,0 ; 0,1 ; 0,25 ; 0,5\right.$ e $\left.1,0 \mathrm{mg} \mathrm{L}^{-1}\right)$; no ensaio 3 , duas concentrações de NAA $\left(0,0\right.$ e $\left.0,01 \mathrm{mg} \mathrm{L}^{-1}\right)$ combinadas com cinco concentrações de cinetina $\left(0,0 ; 0,25 ; 0,5 ; 1,0\right.$ e $\left.2,0 \mathrm{mg} \mathrm{L}^{-1}\right)$; no ensaio 4 , cinco concentrações de AIA $\left(0,0 ; 0,5 ; 1,0 ; 1,5 ;\right.$ e $\left.2,0 \mathrm{mg} \mathrm{L}^{-1}\right)$ e; no ensaio 5 , cinco concentrações de $\mathrm{AG}_{3}\left(0,0 ; 0,1 ; 0,5 ; 1,0\right.$ e $\left.1,5 \mathrm{mg} \mathrm{L}^{-1}\right)$. A utilização de BAP, AIB, NAA e CIN não influenciou o número de brotações. A adição de $0,1 \mathrm{mg} \mathrm{L}^{-1}$ de NAA no meio-de-cultura proporcionou maior comprimento dos brotos por explante, enquanto a concentração de $1,0 \mathrm{mg} \mathrm{L}^{-1}$ de CIN promoveu maior comprimento dos brotos. O uso de $\mathrm{AG}_{3}$ não apresentou efeitos sobre o alongamento das brotações de alecrim-pimenta cultivadas in vitro.

Palavras-chave: Lippia sidoides, planta medicinal, micropropagação, reguladores de crescimento.

(Recebido para publicação em 6 de novembro de 2007; aceito em 18 de março de 2008)

$\mathrm{P}$ epper-rosmarin (Lippia sidoites Chan.; Verbenaceae), a native bush from the Brazilian Northeastern region, where the biome Caatinga predominates, shows its major occurrence in the territory between Bahia and Ceará States. It is popularly known as alecrim-pimenta, alecrim-doNordeste, alecrim-bravo (Inneco et al., 2000), and estrepa-cavalo (Innecco et al., 2000; Matos, 2002). Pepperrosmarin produces an essential oil abundant in thymol and carvacrol, which provides a very strong antimicrobial and antiseptic activity (Macambira et al., 1988). Due to the great economical importance of such species, it may suffer a strong anthropic action and demographic reduction in its natural environment. The essential oil is used in the production of good quality shampoos, tooth pastes, and mouth washers, being also effective in the control of bacterial dental plaque (Nunes, 1999). Seeds from this species were not found. Its propagation is asexual, through the process of stem cutting, using its thinnest branches (Lorenzi \& Matos, 2002) or herbaceous cuttings with leaves (Mendonça, 1997). Hence, the pepper-rosmarin micropopagation turns up as a technique of great application potential.

In micropropagation, culture media are supplemented with growth regulators, whose role is to supply the possible deficiencies of the hormonal endogenous levels in explants (Castro et al., 2002). For Lippia integrifolia (Gris.) Hier, the culture medium Murashige and Skoog (MS) complete or with a reduction to half of the salt, supplemented with $1 \mathrm{mg} \mathrm{L}^{-1}$ of indole butyric acid (IBA) provided a good multiplication rate (Passera \& Ambrosetti, 1999). For Lippia micromera Shau. in DC. var. helleri (Britt.), it was observed that the best multiplication results occurred using the MS medium supplemented with $0,1 \mathrm{mg}$ $\mathrm{L}^{-1}$ of naphthalene acetic acid (NAA) + $2 \mathrm{mg}$ of $\mathrm{L}^{-1}$ of 6-benzylaminopurine (BAP) (Capote et al., 1999). In Lippia alba, cultivar Kavach, there were excellent results for apical buds placed in MS medium containing $2,0 \mathrm{mg} \mathrm{L}^{-1}$ BAP (Gupta et al., 2001). 
The microprogation has been used in the multiplication of several species with medicinal properties. Passera \& Ambrosetti (1999) have developed a fast method for Lippia integrifolia propagation by the use of nodal segments in full or half MS medium (Murashige \& Skoog, 1962). In Lippia junelliana, (Juliani Junior et al., 1999), after studying different propagation methods, the best results were obtained with apical buds and nodal segments in MS medium supplemented with $4.4 \mu \mathrm{M}$ of 6-benzylaminopurine (BAP) or 0.04 ì of indolebutyric acid (IBA) $+4.4 \mu \mathrm{M}$ of BAP. In Lippia alba cultivar Kavach, plant regeneration was obtained by using apical buds in MS medium, containing $2.0 \mathrm{mg} \mathrm{L}^{-1}$ of BAP (Gupta et al., 2001). For Lippia micromera var. helleri, it was noticed that the best multiplication results occurred when using the MS medium, adding $0.1 \mathrm{mg}$ $\mathrm{L}^{-1}$ of naphthalene acetic acid (NAA) + 2,0 $\mathrm{mg} \mathrm{L}^{-1}$ of BAP (Capote et al., 1999). Gibberellins, in the form of gibberellic acid $\left(\mathrm{GA}_{3}\right)$, when used in in vitro multiplication, induce shoot elongation as their main effect, such as observed in Rollinia mucosa (Figueiredo et al., 2001) and macela (Egletes viscose (L.) Less) (Diniz et al., 2003).

The aim of this work was to evaluate the use of different growth regulators in the in vitro multiplication of pepperrosmarin.

\section{MATERIAL AND METHODS}

The assays were held at the Tissue Culture and Plant Breeding Laboratory, at the Department of Agricultural Engineering of the Federal University of Sergipe (UFS). Two-bud nodal segments were used as primary explants. Mother plants grew in greenhouse and were sprayed with $4 \mathrm{~g} \mathrm{~L}^{-1}$ of benomyl, two days before inoculation. The nodal segments, once collected, were washed in current water for 30 minutes, emerged in ethylic alcohol $70 \%$ for 30 seconds, and then in a sodium hypochlorite solution $0,8 \%$ for 16 minutes. After that, they were washed three times in distilled and autoclaved water in a laminar flow camera (Costa, 2006). The explants were inoculated in $250 \mathrm{ml}$ flasks with
$25 \mathrm{ml}$ in MS medium (Murashige \& Shoog, 1962), containing $7 \mathrm{~g} \mathrm{~L}^{-1}$ of agar, and with $\mathrm{pH}$ adjusted to $5.7 \pm 0,1$ before autoclaving $\left(121 \pm 1^{\circ} \mathrm{C}\right.$ and 1,05 atm for 15 minutes). For the multiplication of pepper-rosmarin the following assays were held:

Assay 1: the influence of BAP and IBA - The experimental design was completely randomized in a factorial scheme 4 x 6, where four IBA concentrations $(0.0 ; 0.01 ; 0.05$; and 0.1 $\left.\mathrm{mg} \mathrm{L}^{-1}\right)$ were combined with six BAP concentrations $(0.0 ; 0.1 ; 0.5 ; 1.0 ; 2.0$; and $\left.4.0 \mathrm{mg} \mathrm{L}^{-1}\right)$. The assay was carried out with five replications, each replication with four two-explant flasks.

Assay 2: the influence of NAA The experimental design was completely randomized with five treatments $(0.0 ; 0.1 ; 0.25 ; 0.5$, and 1.0 $\mathrm{mg} \mathrm{L}^{-1}$ of NAA) and five replications, each replication with four two-explant flasks. We added $3 \mathrm{~g} \mathrm{~L}^{-1}$ of active charcoal to the MS medium (Costa, 2006).

Assay 3: the influence of kinetin and NAA - The experimental design was completely randomized, with treatments in a factorial scheme $2 \times 5$, corresponding to two NAA concentrations $\left(0.0\right.$ and $\left.0.01 \mathrm{mg} \mathrm{L}^{-1}\right)$ combined with five kinetin concentrations $(0.0 ; 0.25 ; 0.5 ; 1.0$, and $\left.2.0 \mathrm{mg} \mathrm{L}^{-1}\right)$. The experiment was carried out with four replications, each replication with four two-explant flasks. We added $3 \mathrm{~g} \mathrm{~L}^{-1}$ of active charcoal and $200 \mathrm{mg} \mathrm{L}^{-1}$ of cefotaxime-sodium to the MS medium (Costa, 2006).

Assay 4: the influence of IAA - The experimental design was completely randomized with five treatments $(0.0$; $0.5 ; 1.0 ; 1.5$; and $2.0 \mathrm{mg} \mathrm{L}^{-1}$ of IAA) and five replications of four two-explant flasks each. We added $3 \mathrm{~g} \mathrm{~L}^{-1}$ of active charcoal and $200 \mathrm{mg} \mathrm{L}^{-1}$ of cefotaxinesodium to the MS medium (Costa, 2006).

Assay 5: the influence of $\mathbf{G A}_{3}$ Due to the lack of shoot elongation in the previous assays, five concentrations of $\mathrm{GA}_{3}$ were tested $(0.0 ; 0.1 ; 0.5 ; 1.0$; and $1.5 \mathrm{mg} \mathrm{L}^{-1}$ ) in a completely randomized experiment, with five replications, each with four two-explant bottles. We added $3 \mathrm{~g} \mathrm{~L}^{-1}$ of active charcoal to the MS medium. The $\mathrm{GA}_{3}$ was cold sterilized, in a continuous laminar flow camera (Millipore, 2,2 $\mu \mathrm{m}$ ) and added to the medium during the cooling process (40 to $50^{\circ} \mathrm{C}$ ).

In all assays, cultures were kept in BOD in absence of light, for seven days after inoculation, and then transferred to a growing room with temperature of $25 \pm 2^{\circ} \mathrm{C}$, photon irradiance of $30 \mu \mathrm{mol}$ $\mathrm{m}^{-2} \mathrm{~s}^{-1}$, and photoperiod of 16 hours. In 30 days of inoculation, the following characteristics were evaluated: shoot number and length $(\mathrm{cm})$, number of leaves, and dry mass of the aboveground part (DMAP). Number of leaves and shoots and DMAP were transformed into square root of $(\mathrm{x}+0,5)$ in assays 1 and 2. The same transformation was applied to shoot length in assay 1. Data were submitted to the variance analysis. When the F test was significant, means were compared by the Tukey test $(\mathrm{p} \leq 0.05)$.

\section{RESULTS AND DISCUSSION}

\section{Assay 1: the influence of BAP and}

IBA - There was no significant interaction between BAP and IBA in the micropropagation of pepper-rosmarin for none of the analyzed characteristics. Concerning isolated effects of both growth regulators, concentration $2 \mathrm{mg}$ $\mathrm{L}^{-1}$ of BAP induced the lowest shoot number per explant, although not differing statistically from concentrations 0.1 ; 1.0 ; and $4.0 \mathrm{mg} \mathrm{L}^{-1}$ (Table 1). BAP has been frequently applied to the in vitro multiplication for several species, and there has been variation in the concentrations for the shoot induction, as in Tagetes sp. (0.5 $\mathrm{mg} \mathrm{L}^{-1}$ of BAP) (Turchetto et al., 2005), chapéu-de-couro (Echinodorus $c f$. scaber Rataj.) (1.0 $\mathrm{mg} \mathrm{L}^{-1}$ of BAP) (Pereira et al., 2000a), yagrumo-macho (Didymopanax morototoni) (1.0 $\mathrm{mg} \mathrm{L}^{-1}$ of BAP) (Mantovani et al., 1999), and the Korean-grape (Vitis thumbergii Sieb. et Zucc.) (0.5 $\mathrm{mg} \mathrm{L}^{-1}$ of BAP) (Lu, 2005).

Regarding shoot length by explant, the treatments did not differ statistically among themselves. The absence of increment in the shoot height due to the use of BAP was reported before in the 
in vitro multiplication of the grapevine rootstock Paulsen 1103, causing an inhibitory effect in the shoot growth (Lucas et al, 2006). Considering the number of leaves, the use of $4 \mathrm{mg} \mathrm{L}^{-1}$ BAP produced the highest value, not differing statistically from the treatments with 0 and $1.0 \mathrm{mg} \mathrm{L}^{-1}$ (Table 1). Concentrations of 0 to $0.5 \mathrm{mg} \mathrm{L}^{-1}$ provided the highest values for the aboveground dry mass, although not differing statistically from 0.1 and 1.0 $\mathrm{mg} \mathrm{L}^{-1}$, while these ones did not differ either from concentrations 2.0 and $4.0 \mathrm{mg} \mathrm{L}^{-1}$ (Table 1).

Concerning the presence of IBA, there were no significant differences for none of the evaluated characteristics. Divergent results were obtained in the micropropagation of Lippia juneliana, in which $1.0 \mathrm{mg} \mathrm{L}^{-1}$ of BAP combined with $0.008 \mathrm{mg} \mathrm{L}^{-1}$ of IBA were efficient in shoot induction (Juliani Júnior et al., 1999).

Assay 2: the influence of NAA The studied NAA concentrations did not influence significantly nor shoot and leaf number, neither aboveground dry mass (Table 1). In relation to shoot length, a significant difference among treatments was noticed. The concentration $0.1 \mathrm{mg}$ $\mathrm{L}^{-1}$ induced the longest shoots, although not differing from the check treatment and concentrations 0.25 and $0.5 \mathrm{mg} \mathrm{L}^{-1}$, but only from the concentration $1.0 \mathrm{mg}$ $\mathrm{L}^{-1}$ (Table 1). These results show that higher concentrations of such auxin may inhibit shoot length.

Assay 3: the influence of kinetin and NAA - There was nor significant interaction between kinetin and NAA, neither kinetin significant effects over shoot and leaf number (Table 1). Different results were obtained in Cissus sicyoides establishment and in vitro multiplication, in which the best rates for shoot numbers and length were reached in the presence of $0.99 \mathrm{mg} \mathrm{L}^{-1}$ of kinetin and $0.58 \mathrm{mg} \mathrm{L}^{-1}$ of NAA (Abreu et al., 2003). Positive effects were also observed in the multiplication of Salix humboldtiana (Pereira et al., 2000b) and Ficus carica L. (Fraguas et al., 2004).

Table 1. Shoot number and length, leaf number, and aboveground dry mass of in vitro explants of pepper-rosmarin as function of BAP, NAA, and kinetin concentration in MS culture medium (número e comprimento de brotos, número de folhas e massa seca da parte aérea de explantes in vitro de alecrim-pimenta, em função de concentrações de BAP, NAA e cinetina no meio de cultura MS). São Cristóvão, UFS, 2006.

\begin{tabular}{|c|c|c|c|c|}
\hline BAP (mg L-1) & Shoot number ${ }^{1}$ & $\begin{array}{l}\text { Shoot length } \\
(\mathrm{cm})^{2}\end{array}$ & Leaf number ${ }^{1}$ & $\begin{array}{l}\text { Dry mass of the } \\
\text { aerial part }(\mathrm{g})^{1}\end{array}$ \\
\hline 0 & $2.4 \mathrm{a}$ & $0.34 a$ & $9.4 a b$ & $0.008 a$ \\
\hline 0.1 & $2.0 a b$ & $0.35 a$ & $9.0 \mathrm{ab}$ & $0.007 a b$ \\
\hline 0.5 & $2.3 \mathrm{a}$ & $0.34 a$ & $9.1 \mathrm{ab}$ & $0.007 \mathrm{a}$ \\
\hline 1 & $1.9 a b$ & $0.26 a$ & $8.8 a b$ & $0.005 a b$ \\
\hline 2 & $1.6 \mathrm{~b}$ & $0.27 \mathrm{a}$ & $6.8 \mathrm{~b}$ & $0.004 \mathrm{~b}$ \\
\hline 4 & $2.2 \mathrm{ab}$ & $0.30 \mathrm{a}$ & $10.8 \mathrm{a}$ & $0.005 b$ \\
\hline CV (\%) & 14.48 & 7.32 & 21.60 & 0.31 \\
\hline \multicolumn{5}{|l|}{ NAA $\left(\mathrm{mg} \mathrm{L}^{-1}\right)$} \\
\hline 0.00 & $2.3 \mathrm{a}$ & $0.62 a b$ & $24.0 \mathrm{a}$ & $0.021 \mathrm{a}$ \\
\hline 0.10 & $2.9 \mathrm{a}$ & $0.83 a$ & $23.7 \mathrm{a}$ & $0.037 \mathrm{a}$ \\
\hline 0.25 & $2.6 \mathrm{a}$ & $0.70 a b$ & $18.3 \mathrm{a}$ & $0.034 \mathrm{a}$ \\
\hline 0.50 & $2.7 \mathrm{a}$ & $0.43 a b$ & $18.0 \mathrm{a}$ & $0.027 \mathrm{a}$ \\
\hline 1.00 & $2.2 \mathrm{a}$ & $0.34 \mathrm{~b}$ & $15.0 \mathrm{a}$ & $0.015 a$ \\
\hline $\mathrm{CV}(\%)$ & 18.82 & 9.98 & 23.59 & 1.77 \\
\hline \multicolumn{5}{|c|}{ kinetin ( $\left.\mathrm{mg} \mathrm{L}^{-1}\right)$} \\
\hline 0.00 & $3.3 \mathrm{a}$ & $0.88 a b$ & $18.5 \mathrm{a}$ & $0.024 \mathrm{a}$ \\
\hline 0.25 & $3.0 \mathrm{a}$ & $0.72 \mathrm{~b}$ & $16.7 \mathrm{a}$ & $0.018 a b$ \\
\hline 0.50 & $2.5 \mathrm{a}$ & $0.77 \mathrm{~b}$ & $14.0 \mathrm{a}$ & $0.016 \mathrm{~b}$ \\
\hline 1.00 & $2.9 \mathrm{a}$ & $1.17 \mathrm{a}$ & $18.0 \mathrm{a}$ & $0.022 \mathrm{a}$ \\
\hline 2.00 & $3.3 \mathrm{a}$ & $0.81 \mathrm{~b}$ & $18.7 \mathrm{a}$ & $0.023 \mathrm{a}$ \\
\hline$\overline{C V}(\%)$ & 21.51 & 26.32 & 23.28 & 17.77 \\
\hline
\end{tabular}

Means followed by the same letter in the columns, did not differ from each other, Tukey test, $\mathrm{p} \leq 0,05$ (médias seguidas de mesma letra nas colunas não diferem estatisticamente entre si pelo teste de Tukey, $\mathrm{p} \leq 0,5) .{ }^{1 /}$ Data transformed to arc sen of the square root of $(\mathrm{x}+0.5)$, for assays 1 (BAP x IBA) and 2 (NAA) (dados transformados para arco seno de raiz de (x + $0,5)$, para o ensaio 1 (BAPxAIB) e 2 (ANA)); ${ }^{2} /$ Data transformed to arc sen of the square root of $(x+0.5)$ for assay (dados transformados para arco seno de raiz de $(x+0,5)$ para $o$ ensaio 1).

Shoot length was significantly altered in response to differences in the kinetin concentration. The concentration $1.0 \mathrm{mg} \mathrm{L}^{-1}$ resulted in the longest shoots, although not differing from the check treatment (Table 1). Concerning aboveground dry mass, it was noticed that the absence of kinetin improved mass accumulation, although not differing from the concentrations 0.25 , 1.0 , and $2.0 \mathrm{mg} \mathrm{L}^{-1}$.

Assay 4: the influence of IAA Shoot number and length and number of leaves did not present significant differences as function of the use of IAA. This suggests that the auxin endogenous level in the explants was sufficient for their regeneration.

Assay 5: the influence of $\mathbf{G A}_{3}-\mathrm{GA}_{3}$ did not induce the expected shoot elongation in pepper-rosmarin. In fact, there were no significant differences among treatments in any of studied characteristics. In this study, a high percentage of vitrified plants was observed (data not showed) as the concentration of $\mathrm{GA}_{3}$ was increased. Similar results were obtained in Tournifurtia paniculata nodal segments (Bertolucci et al., 2000) and in macela (Diniz et al., 2003), in which the presence of $\mathrm{GA}_{3}$ induced hyperhydration and alteration in leaf shape.

We concluded that the use of BAP, IBA, NAA, and kinetin did not influence shoot number. The addition of $0.1 \mathrm{mg}$ $\mathrm{L}^{-1}$ of NAA or $1.0 \mathrm{mg} \mathrm{L}^{-1}$ of kinetin to the culture medium improved shoot length. $\mathrm{GA}_{3}$ did not have any effect on pepper-rosmarin shoot length under in vitro culture conditions. 


\section{REFERENCES}

ABREU IN; PINTO JEBP; BERTOLUCCI SKV; MORAIS AR; GEROMEL C; LADEIRA, A; LAMEIRA OA. 2003. Propagação in vivo e in vitro de Cissus sicyoides: uma planta medicinal. Acta Amazônica 33: 1-7.

BERTOLUCCI SKV; PINTO JEBP; CARDOSO MG; GAVILANES ML; SANTIAGO EJA; LAMEIRA OA. 2000. Micropropagação de Tournefortia cf paniculata Cham. Revista Brasileira de Plantas Medicinais Botucatu 3: 43-49.

CAPOTE A; FUENTES V; BLANCO N; PEREZ O. 1999. Micropropagacion y regeneration de plantas in vitro de oreganillo Lippia micromera Schau. Revista del Jardin Botanico Nacional 20: $139-142$

CASTRO PRC; SENA JOA; KLUGE, RA. 2002. Introdução à fisiologia do desenvolvimento vegetal. Maringá: Eduem. 255p.

COSTA AS. 2006. Sustentabilidade da produção de alecrim-pimenta (Lippia sidoides Cham.): micropropagação visando a conservação in vitro. São Cristóvão: UFS. 56 p. (Tese mestrado)

DINIZ JDN; ALMEIDA JL; TEIXEIRA ALA.; GOMES ES; HERNANDEZ FFF. 2003. Ácido giberélico $\left(\mathrm{GA}_{3}\right)$ e 6-benzilaminopurina (BAP) no crescimento in vitro de macela [Egletes viscosa (L.) Less.]. Ciência e Agrotecnologia 27: 934-938.

FIGUEIREDO SFL; ALBARELLO N; VIANA VRC. 2001. Micropropagation of Rollinia mucosa (Jacq.) Baill. In Vitro Cell Developmental Biology Plant 37: 471-475.

FRÁGUAS CB; PASQUAL M; PEREIRA AR. 2004. Multiplicação in vitro de Fícus carica L. efeito da cinetina e do ácido giberélico. Ciência e Agrotecnologia 28: 49-55.
GUPTA SK; KHANUJA SPS; KUMAR S. 2001. In vitro micropropagation of Lippia alba. Current Science 81: 206-210.

INNECCO R; MATTOS SH; CRUZ GF. 2000. Determinação da altura de corte do alecrimpimenta. Horticultura Brasileira 18: 992-993.

JULIANI JUNIOR HR; KOROCH AR; JULIANI HR; TRIPPI VS. 1999. Micropropagation of Lippia junelliana (Mold.) Tronc. Plant Cell, Tissue and Organ culture 59: 175-179.

LORENZI H; MATOS FJA. 2002. Plantas medicinais no Brasil: nativas e exóticas. Nova Odessa: Instituto Plantarum, 512p.

LU MC. 2005. Micropropagation of Vitis thunbergii Sieb. Et Zucc., a medicinal herb, through high-frequency shoot tip culture. Scientia Horticulturae 107: 64-69.

LUCAS MK; SAMPAIO NV; PEREIRA DD; SAMPAIO TG; PERES GS; FAGUNDES JD. 2006. Multiplicação in vitro do porta-enxerto de videira Paulsen 1103 com benzilaminopurina e ácido indolbutórico. Plant Cell Culture \& Microprogagation 2:29-34.

MACAMBIRA LMA; ANDRADE CHS; CRAVEIRO AA; MATOS FJA; BRAZ FILHO R. 1988. Contribuição ao conhecimento químico de plantas do nordeste. Acta Amazônica 18: 449-452.

MACHADO MP; CARVALHO DC; BIASI LA. 2004. Multiplicação in vitro do porta-enxerto de macieira "Marubakaido" em diferentes meios de cultivo e concentrações de ácido giberélico. Scientia Agraria 5: 69-72.

MATOS FJA. 2002. Farmácias vivas: sistema de utilização de plantas medicinais projetado para pequenas comunidades. Fortaleza: UFC. 267p.

MANTOVANI NC; FRANCO ETH; GUERRA M.P; HOPPE JM. 1999. Micropropagação de caixeta, Didymopanax morototoni (Aubl.) Dcne. et Planch. Ciência Florestal 9: 47-61.
MENDONÇA CS. 1997. Efeito do ácido indol butírico no enraizamento de estacas de alecrim-pimenta (Lippia sidoides Cham.). Fortaleza: UFC. 43p (Tese mestrado).

MURASHIGE T; SKOOG F. 1962. A revised medium for rapid growth and bioassys with tobacco tissue cultures. Physiologia Plantarum 15: 473-479.

NUNES RS. 1999. Desenvolvimento galênico de produtos, de uso odontológico (creme dental e enxaguatório bucal) a base de Lippia sidoides Cham Verbenaceae alecrim-pimenta. Olinda: UFPE. 300 p. (Tese mestrado).

PASSERA CB; AMBROSETTI JA. 1999. In vitro propagation of "Incayuyo", Lippia intergrifolia (Gris.) Hier. (Verbenaceae), a medicinal and aromatic plant of Monte Phytogeographical Province, Argentina. Acta Horticulturae 502: 319-324.

PEREIRA FD; PINTO JEBP; CARDOSO MG; LAMEIRA OA. 2000a. Propagação in vitro de chapéu-de-couro (Echinodorus cf. scaber RATAJ.), uma planta medicinal. Ciência $e$ agrotecnologia 24: 74-80.

PEREIRAAMS; BERTONI BW; MORAES RM; FRANCA SC. 2000b. Micropropagation of Salix humboldtiana Hild. Revista Brasileira de Plantas Medicinais 2: 17-21.

SANTA-CATARINA C; MACIEL SC; DENARDI F; PEDROTTI EL. 2001. Micropropagação do porta-enxerto de macieira "Seleção 69" tolerante à podridão do colo (Phytophthora cactorum). Ciência Rural 31: 757-762.

TURCHETTO AC; NASSI FL; ZANANDREA I; FIGUEIREDO PM; PETERS JA; BRAGA EJ. 2005. Multiplicação in vitro de Tagetes sp. In: CONGRESSO BRASILEIRO DE OLERICULTURA, 45. Resumos... Fortaleza: CBO (CD-ROM). 